Ritrýnd grein birt 31. desember 2021

\title{
Andleg líðan unglinga í 10. bekk: Niðurstöður úr fyrirlögn Short Warwick-Edinburgh Mental Well-Being kvarðans
}

\author{
Ársæll Arnarsson og Sunna Gestsdóttir \\ Abstract $\longrightarrow$ Um höfunda $\longrightarrow$ About the authors $\rightarrow$ Heimildir
}

Mikilvægi andlegrar heilsu og vellíðanar meðal unglinga hefur verið sífellt meira áberandi í umræðunni. Í alpjóðlegu rannsókninni Health Behaviour in School-Aged Children (HBSC), sem er sú stærsta á sviði heilsu og líðanar unglinga, er andleg líðan mæld með ýmsum hætti. Vaxandi áhyggjur af hrakandi andlegri líðan hefur hins vegar hvatt til frekari og ítarlegri mælinga á pessum páttum. Í sỉoustu fyrirlögn HBSC var styttri útgáfu af Warwick-Edinburgh spurningalistanum (Short Warwick-Edinburgh Mental Well-Being Scale - SWEMWBS) bætt við á öllum Norðurlöndunum. Tilgangur rannsóknarinnar var að meta aðgreiniréttmæti SWEMWBS samanborið við aðrar breytur HBSC-listans og að bera niðurstöðurnar saman við útkomu meðal eldri Íslendinga. SWEMWBS inniheldur sjö atriði sem eru orðuð með jákvæðum hætti og beinast að jákvæðum páttum. Mælitækið hefur reynst áreiðanlegt í ítrekuðum fyrirlögnum og í pessari rannsókn var Cronbach's alfa 0,90. Alls svöruðu 2.245 nemendur í 10. bekk spurningalista rannsóknarinnar pegar hún var lögð fyrir veturinn 2017-2018. Af peim voru 1.1084 strákar (48,4\%), 1.111 stelpur (49,5\%) og 48 (2,1\%) sem skilgreindu kyn sitt sem „Annað“. Meðalskor á SWEMWBS fyrir alla 10. bekkinga sem tóku pátt í rannsókninni var 24,8. Meðaltal fyrir stráka var 25,7 og 24,2 fyrir stelpur en 19,8 fyrir pá sem skilgreindu kyn sitt með öðrum hætti. Bakgrunnsbreytur eins og fjárhagsstaða fjölskyldu, fæðingarland og tengsl við fjölskyldu, skóla og vini, höfðu allar áhrif á dreifing skora á SWEMWBS. Sterk fylgni reyndist á milli bæði heildarskors á SWEMWBS og einstakra atriða annars vegar, og peirra breyta sem áður höfðu verið notaðar til að meta líðan í HBSC-rannsókninni eins og Cantril-sjónhendingarkvarðans, mati á eigin heilsu og HBSC Symptom Checklist. Pað var pó augljóst að SWEMWBS mældi ekki nákvæmlega sömu pætti og pær breytur sem áður höfðu verið notaðar. SWEMWBS er pví fýsilegur kostur við mat á andlegri líðan ungs fólks.

Efnisorð: SWEMWBS, Warwick-Edinburgh, unglingar, HBSC.

\section{Inngangur}

Alpjóðaheilbrigðismálastofnunin skilgreinir andlega heilsu sem ástand vellíðanar par sem einstaklingurinn gerir sér grein fyrir eigin hæfni, getur tekist á við eðlilega streitu, náð árangri í starfi og lagt til samfélagsins. Petta er víðfeðm skilgreining sem tekur til hugrænnar og félagslegrar virkni auk margra pátta í umhverfinu (WHO, 2004). Par kemur fram sú skoðun að andleg vellíðan felist ekki aðeins í pví að vera laus við sálræna kvilla. Hún dregur einnig fram báða pætti hinnar heimspekilegu rökræðu um vellíðan sem hefur verið ráðandi allt frá Aristótelesi fram til daga jákvæðrar sálfræði. Par hafa menn tekist á um gildi pess, annars vegar að upplifa ánægju á líðandi stund, hedónía (e. hedonia) og hins vegar að gera verðuga hluti, eudaímónía (e. eudaimonia). Hedóníski hlutinn snýr að pví að líða vel með lífið, vera hamingjusamur, finna fyrir ánægju og vera laus við ópægindi. Eudaímóníska 
sjónarhornið beinist hins vegar að möguleika mannsins, merkingu og sjálfspekkingu. Í pví samhengi snýst vellíðan frekar um virkni einstaklingsins (Ryan og Deci, 2001). Nú á tímum er almennt litið svo á að til pess að öðlast farsæld í lífinu purfi bæði hedóníu og eudaímoníu, pannig að bæði eru nauðsynleg en hvorug eru nægjanleg forsenda pess að lifa góðu lífi (Haver o.fl., 2015).

Mikilvægi andlegrar heilsu og vellíðanar meðal unglinga hefur verið sífellt meira áberandi í umræðunni. Í augum bæði vísindamanna og yfirvalda hefur petta æviskeið öðlast stærri sess par sem mörg peirra vandamála sem fólk glímir við síðar á ævinni virðast eiga uppruna sinn par (Paus o.fl., 2008). Petta á sérstaklega við um geigvænlega tíðni kvíða og punglyndis meðal unglinga (Sawyer o.fl., 2007). Heilbrigð aðlögun að peim breytingum sem unglingsárin hafa í för með sér hefur fjölpætt áhrif á líf einstaklinga til lengri tíma. Detta pýðir að faraldsfræðilegar rannsóknir á andlegri heilsu unglinga eru mikilvægar til pess að segja fyrir um heilsufar pjóða í framtíðinni. Að auki veita pær áríðandi upplýsingar um hvernig megi auka líkurnar á að unglingar geti farið í gegnum petta æviskeið með farsælum hætti (Eriksson o.fl., 2019; O’Connor o.fl., 2017). Pó mikilvægi forvarna gegn geðrænum kvillum verði seint vanmetið, er ljóst að einnig er nauðsynlegt að skoða andlega heilsu út frá öðrum sjónarhornum. Рað á til dæmis við um skilgreiningar og mælingar á jákvæðum páttum hennar (Eriksson o.fl., 2019). Margir unglingar mælast ekki með nein klínísk einkenni geðsjúkdóma en finna samt fyrir lakari virkni en jafnaldrar peirra (Suldo o.fl., 2011). Rannsókn á 1.234 bandarískum unglingum sem notaði nokkrar yfirgripsmiklar mælingar á vellíðan, sýndi að meira en helmingur pátttakendanna náði ekki lágmarksskori fyrir góða andlega heilsu og að tîðni slæmrar heilsu jókst með auknum aldri (Keyes, 2006).

Í tvípátta líkaninu af andlegri heilsu (e. dual-factor model of mental health) er lögð áhersla á að mæla ekki einvörðungu merki um sjúkleika heldur einnig um heilbrigði. Pessir tveir pættir eru tengdir en samt aðskildir (Greenspoon og Saklofske, 2001). Pess utan parf að skoða andlega heilsu með heildrænum hætti, p.e. að líta ekki aðeins á einstaklinginn sem einkennalausan heldur skoða jafnframt hvort hann upplifi jákvæðar tilfinningar, innihald í lífi sínu og að hann leggi eitthvað til (Ryff og Singer, 1998). Prátt fyrir að jákvæð sálfræði hafi skapað sér sess innan fræðanna á undanförnum áratugum, er meginpungi rannsókna á andlegri heilsu unglinga samt á geðsjúkdóma (Evans o.fl., 2005). Раð pýðir að porra peirra einstaklinga, sem hefur ekki klínísk einkenni, en upplifir samt litla lífsánægju og gæti pví lent í erfiðleikum síðar á ævinni, er enginn gaumur gefinn (Greenspoon og Saklofske, 2001).

Vellíðan er einnig mikilvægur páttur í andlegu heilbrigði ungmenna sem eru greind með geðsjúkdóma og pví hvernig pau ná að aðlaga sig að aðstæðum. Í rannsókn á bandarískum unglingum, komust Suldo og Schaffer (2008) að pví að 57\% peirra töldust vera við góða andlega heilsu, 13\% voru án klínískra einkenna en upplifðu litla lífsánægju, 13\% uppfylltu greiningaskilmerki en voru samt ánægð með lífið og 17\% voru bæði með einkenni sjúkdóms og litla lífsánægju. Slíkar rannsóknir sýna fram á hversu mikilvægt pað er að skoða andlega heilsu með víðu sjónarhorni.

Í alpjóðlegu rannsókninni Health Behaviour in School-Aged Children (HBSC), sem er sú stærsta á sviði heilsu og líðanar unglinga, er andleg líðan mæld með ýmsum hætti. Meðal peirra mælitækja sem notuð eru er lífsánægjukvarði Cantrils sem var fyrst gefinn út árið 1965. Um er að ræða sjónhendingarkvarða sem er settur upp sem stigi og er fólk beðið um að meta lífsánægju sína frá 0 upp í 10 .

Önnur mæling á líðan sem notuð er í HBSC-rannsókninni er mat á eigin heilsu (e. self-rated health). Petta er ein mikilvægasta breytan í spurningalistanum (Inchley o.fl., 2020) og hefur sýnt sig vera næm bæði fyrir áhrifum aldurs og kyns (Cavallo o.fl., 2006). Pá hafa Kelleher o.fl. (2007) sýnt fram á tengsl milli mats á eigin heilsu og ýmissa félagssálfræðilegra, lýðfræðilegra og heilsutengdra breyta.

Mat á eigin heilsu byggir á skynjun og túlkun einstaklingsins á eigin heilsufari og meðvituðum eða ómeðvituðum samanburði við jafnaldra (Bjorner, 1996). Hægt er að aðgreina petta mat frá öðrum sértækari heilsufarsbreytum pví um er að ræða alhliða hugmynd um heilsu frekar en samanlagða niðurstöðu ýmissa pátta. 
Priðja mælitækið sem HBSC-rannsóknin notar til að leggja mat á líðan nefnist „HBSC-Symptoms Checklist" og var pað próað til að meta tíðni sállíkamlegra umkvartana (e. psychosomatic complaints). Pær vísa til einkenna sem einstaklingar upplifa, óháo pví hvort peir hafi klíníska sjúkdómsgreiningu. Höfuðverkur, magaverkur, pirringur og kvíði eru algengustu sállíkamlegu umkvartanirnar. Fyrri rannsóknir hafa sýnt að stór hluti unglinga hefur vikulega eða oftar slíkar umkvartanir og pær eru til að mynda helsta ástæða pess að peir mæta ekki í skólann (Mikkelsson o.fl., 1997). Pær hafa einnig sterk tengsl við vanlíðan og litla lífsánægju (Ravens-Sieberer o.fl., 2009).

Prátt fyrir að HBSC-rannsóknarnetið hafi frá upphafi lagt mikla áherslu á að rannsaka líðan unglinga eins og best sést á vali peirra á breytum til skoðunar, pá hefur sá áhugi jafnvel enn eflst á síðastliðnum árum í takti við stærri samfélagslega próun. Í fyrirlögninni veturinn 2017-2018 sannmæltust öll Norðurlöndin að setja inn fleiri mælitæki sem sneru að andlegri líðan, sérstaklega með pað í huga að skoða hana einnig út frá jákvæðari hliðum (Eriksson o.fl., 2019).

Warwick-Edinburgh vellíðanarkvarðinn (Warwick-Edinburgh Mental Well-Being Scale WEMWBS) var próaður í Bretlandi til að mæta vaxandi pörf fyrir öflugar sálmælingar sem hægt væri að nota til að fylgjast með andlegri líðan almennings og meta árangur af ýmsum verkefnum, inngripum og stefnumótandi aðgerðum sem ætlað var að auka vellíðan (Tennant o.fl., 2007). Hann innihélt 14 atriði sem valin voru af hópi sérfræðinga eftir viðamikla úttekt á fyrirliggjandi vísindarannsóknum, eigindlegum rannsóknum með rýnihópa og sálmælingalega skoðun. Yfirborðsréttmæti var metið gott og kvarðinn tók á flestum peim atriðum sem tengjast jákvæðum eiginleikum andlegrar heilsu, p.m.t. jákvæðum tilfinningum, nærandi samböndum og jákvæðri virkni. Hins vegar póttu nokkur atriði pað lík að óhætt væri að fækka atriðum í listanum par sem pau bættu engum nýjum upplýsingum við (Stewart-Brown o.fl., 2009). Dví var útbúin styttri útgáfa af Warwick-Edinburgh spurningalistanum (Short Warwick-Edinburgh Mental Well-Being Scale - SWEMWBS) sem inniheldur sjö atriði sem eru orðuð með jákvæðum hætti og beinast að jákvæðum páttum (Stewart-Brown o.fl., 2009). Mælitækið hefur reynst áreiðanlegt í ítrekuðum fyrirlögnum bæði meðal fullorðinna og ungmenna. Mælingar á fullorðnum t.d. í Svípjóð og Noregi hafa leitt í ljós áreiðanleikastuðul, Cronbach's alfa, upp á 0,83 og 0,84 (Haver o.fl., 2015). Meðal ungmenna í Noregi mældist Cronbach's alfa 0,88 í rannsókn Ringdal og félaga (2018). Prátt fyrir að atriðin séu ekki mörg, sjást sjaldan pak- eða gólfáhrif (Dóra Guðrún Guðmundsdóttir, 2011). Kvarðinn er auðskiljanlegur, hagnýtur og auðveldur í fyrirlögn í stórum úrtökum (Stewart-Brown o.fl., 2009) og er nú notaður í rannsóknum á andlegri líðan í mörgum löndum (Koushede o.fl., 2019). Réttmætisrannsóknir hafa verið framkvæmdar í ýmsum undirhópum, s.s. meðal unglinga, minnihlutahópa og í klínískum úrtökum (McKay og Andretta, 2017; Smith o.fl., 2017; Trousselard o.fl., 2016). Kvarðinn hefur verið pýddur á hartnær 30 tungumál, par á meðal íslensku og réttmætisrannsóknir hafa verið gerðar á fjölmörgum peirra (Koushede o.fl., 2019).

Á Íslandi hefur SWEMWBS verið lagður fyrir úrtak fólks á aldrinum 18-69 ára sem hluti af rannsókninni Heilsa og líðan Íslendinga sem Embætti landlæknis hefur staðið fyrir frá árinu 2007. Í pví samhengi hefur listinn meðal annars verið notaður til að greina áhrif efnahagshrunsins á andlega lỉðan Íslendinga (Unnur Jónsdóttir, 2018). Í greiningu á svörum 6.344 svarenda sem tóku pátt í rannsókninni Heilsa og líðan Íslendinga árið 2017, reyndist meðalskor yfir alla aldurshópa vera 25,4. Pegar aldurshóparnir voru flokkaðir kom í ljós að meðalskorið - og par með vellíðanin - jókst með hækkandi aldri; úr 23,6 meðal peirra sem voru 18 til 25 ára, upp í 26,8 hjá peim sem voru 65 ára eða eldri. Enginn stórvægilegur munur reyndist hins vegar á svörum karla og kvenna, 25,5 á móti 25,3 (Koushede o.fl., 2019).

Tilgangur pessarar rannsóknar var að skoða fýsileika pess að nota SWEMWBS til að meta jákvæða andlega líðan meðal 10. bekkinga á Íslandi. Pað var gert með pví að bera útkomuna fyrir pennan aldurshóp saman við niðurstöður SWEMWBS hjá eldri Íslendingum. Einnig var skoðuð fylgnin milli útkomu á SWEMWBS og útkomu á öðrum breytum sem tengdust líðan, p.m.t. mælingu á lífsánægju, mati á eigin heilsu og sállíkamlegum einkennum. Рað var gert til að kanna aðgreiniréttmæti SWEMWBS samanborið við pær breytur sem fyrir eru í HBSC-spurningalistanum. Tilgáta okkar 
var sú að SWEMWBS myndi sýna sterkari fylgni við pær breytur sem legðu mat á andlega frekar en líkamlega heilsu. Að lokum var útkoma á SWEMWBS skoðuð í tengslum við ýmsar bakgrunnsbreytur sem vitað er að geta haft áhrif á líðan unglinga.

\section{Аðferð}

\section{HBSC-rannsóknin}

Heilsa og lífskjör skólabarna er fjölpjóðleg rannsókn, studd af Alpjóðaheilbrigðismálastofnuninni (WHO), par sem unglingar í 6., 8. og 10. bekk grunnskóla eru spurðir um heilsu, lí̉an og félagslegar aðstæður (Inchley o.fl., 2020). Fyrsta fyrirlögnin fór fram veturinn 1983-1984 og hefur hún síðan verið endurtekin fjórða hvert ár. Frá árinu 2006 hefur pessi rannsókn verið lögð fyrir á Íslandi. Síðasta fyrirlögn var veturinn 2017-2018 og fengust pá svör frá 7.159 nemendum. Í pessari greiningu er aðeins notast við svör nemenda í 10. bekk.

\section{Framkvemd}

Áður en gagnasöfnun hófst veturinn 2017-2018 var spurningalistinn sendur, ásamt rannsóknaráætlun, til Persónuverndar og Vísindasiðanefndar Háskóla Íslands. Engar athugasemdir voru gerðar við fyrirhugaða framkvæmd. Að pví loknu voru sömu upplýsingar sendar öllum skólastjórum á Íslandi sem höfðu nemendur í 6., 8. eða 10. bekk og pess óskað að peirra skólar tækju pátt. Síðan var öllum foreldrum og forráðamönnum sent kynningarbréf og peim gefið tækifæri til að hafna pátttöku sinna barna.

Fyrirlagning spurningalistans var með rafrænum hætti. Borð nemenda voru færð í sundur til pess að tryggja að svarendur sæju ekki svör annarra og svo opnaði hver og einn sinn lista á sinni tölvu. Í upphafi var stutt lýsing á rannsókninni ásamt skilaboðum pess efnis að jafnvel pótt foreldrar peirra og skólayfirvöld hefðu gefið leyfi, pá væri nemendum sjálfum algjörlega frjálst að neita pátttöku eða að sleppa að svara ákveðnum spurningum. Pá var ítrekað að um nafnlausa könnun væri að ræða.

\section{Mælitæki}

Styttri útgáfan af Warwick-Edinburgh spurningalistanum (Short Warwick-Edinburgh Mental Well-Being Scale - SWEMWBS) var lögð fyrir nemendur í 10. bekk í pátttökuskólum. Hann inniheldur eftirfarandi sjö fullyrðingar sem eru orðaðar með jákvæðum hætti og beinast að jákvæðum páttum:

1. Ég hef verið bjartsýn/n um framtíðina

2. Mér hefur pótt ég gera gagn

3. Ég hef verið afslöppuð/afslappaður

4. Mér hefur gengið vel að takast á við vandamál

5. Ég hef hugsað skýrt

6. Mér hefur fundist ég vera náin/n öðrum

7. Ég hef átt auðvelt með að taka ákvarðanir

Við hverja fullyrðingu voru fimm svarmöguleikar sem gáfu mismörg stig í útreikningi á útkomu kvarðans. „Aldrei“ gaf 1 stig, „Sjaldan“ gaf 2 stig, „Stundum“ gaf 3 stig, „Oft“ gaf 4 stig og „Alltaf“ gaf 5 stig. Lægsta mögulega samanlagða skorið var pví 7 en hið hæsta 35.

Lífsánægja pátttakenda (Cantril, 1965) var metin með sjónhendingarkvarða (e. visual analog scale) Cantrils. Fyrirmælin voru svohljóðandi: „Hér er mynd af stiga. Efst í stiganum er talan '10' sem táknar besta hugsanlega lífið sem pú gætir átt og neðst er talan ‘0’ sem táknar versta hugsanlega lífið 
sem að pú gætir átt. Hvar í pessum stiga er líf pitt núna? Merktu í reitinn há peirri tölu sem lýsir lífi pínu best."

Pátttakendur voru einnig beðnir um að leggja mat á eigin heilsu með pví að svara spurningunni: „Myndir pú segja að heilsa pín væri...?" par sem svarmöguleikarnir voru „Framúrskarandi“, „Góð“, „Sæmileg“ og „Léleg“. Í peirri greiningu sem hér fer á eftir fengu svarmöguleikarnir gildin frá 4 niður í1.

Sállíkamlegar umkvartanir voru mældar með átta fullyrðingum HBSC-Symptom Checklist og voru nemendur beðnir um að svara pví hversu oft síðastliðna sex mánuði peir hefðu fundið fyrir eftirfarandi: a) höfuðverkjum, b) magaverkjum, c) bakverkjum, d) depurð, e) pirringi eða skapvonsku, f) kvíða, g) svefnörðugleikum eða h) svima. Svarmöguleikarnir við hverja spurningu voru fimm og voru kóðaðir sem hér segir: „Sjaldan eða aldrei“=5; „Um pað bil mánaðarlega“ $=4$; „Um pað bil vikulega“=3; „Oftar en einu sinni í viku“ $=2$; og „Hér um bil daglega“ $=1$. Svörin við öllum átta fullyrðingunum voru síðan lögð saman og fékkst pá útkoma sem var ein samtala á bilinu 0 upp í 32, par sem hærra gildi benti til meiri umkvartana. Í frekari úrvinnslu á niðurstöðum voru búnir til tveir flokkar; annars vegar flokkur sem tengdist meira líkamlegum einkennum (p.e. höfuðverkjum, magaverkjum og bakverkjum) og hins vegar flokkur sem tengdist frekar sálrænum einkennum (p.e. depurð, pirringi eða skapvonsku, kvíða, svefnörðugleikum og svima).

Upplifun unglinganna af fjárhagsstöðu fjölskyldu sinnar var metin með spurningunni: „Hversu gott telur pú fjölskylduna pína hafa pað fjárhagslega?“ Svarmöguleikarnir voru „Mjög gott“, „Gott“, „Miðlungs“, „Slæmt“ og „Mjög slæmt“. Pessi spurning var próuð til pess að fá fram huglægt mat unglinga á félagslegri hagstöðu sinni. Hún hefur verið notuð í fjölda rannsókna og hefur sýnt sig geta spáð vel fyrir um ójöfnuð í heilsu (Torsheim o.fl., 2018).

Styrkur tengsla unglinga við foreldra sína var metinn með pví að slá saman fjórum spurningum sem allar spurðu út í tengsl við kynforeldra og einnig stjúptengsl ef pau voru fyrir hendi (Ársæll Arnarsson, 2019; Ársæll Arnarsson o.fl., 2020). Nemendurnir voru beðnir um að segja til um hversu auðvelt peir ættu með að tala um pað sem ylli peim áhyggjum við föður sinn, móður sína, stjúpföður eða stjúpmóður. Svarmöguleikarnir voru fimm: 1) „Mjög auðvelt“, 2) „Auðvelt“, 3) „Erfitt“, 4) „Mjög erfitt“ og 5) „Á ekki við eða hitti ekki viðkomandi“. Svörin við spurningunum voru kóðuð pannig að gildið 1 táknaði slök tengsl og í pann flokk féllu peir unglingar sem sögðust eiga erfitt eða mjög erfitt með að tala við foreldra sína. Peir unglingar sem sögðust ekki eiga eða ekki hitta foreldra voru einnig settir í pennan flokk. Peir sem sögðust eiga auðvelt með að tala við foreldra fengu gildið 2 sem táknar góð tengsl og ef samskiptin voru mjög auðveld fengu peir gildið 3. Kóðunin var hins vegar aðallega gerð til pess að reikna út samtölu fyrir tengsl við foreldra, p.e. að skoða ekki einungis áhrif eins foreldris heldur tveggja eða fleiri par sem pað átti við. Í peim útreikningi var stuðst við einfalda formúlu Andersen og Dæhlen (2017), par sem gildin frá 1 upp í 3 eru lögð saman og deilt í með tveimur ef um tvo foreldra er að ræða, premur ef foreldrarnir eru prír og fjórum ef unglingurinn hefur metið samskipti við föður, móður, stjúpföður og stjúpmóður. Рað pýðir t.d. að unglingur sem á tvo foreldra og segist vera í góðum tengslum við stjúpföður (gildið 2) og mjög góðum tengslum við móður (gildið 3) fær samtöluna 2,5. Unglingur sem á prjá foreldra og segist vera í mjög góðum tengslum við móður og stjúpmóður (tvisvar sinnum gildið 3) en slökum tengslum við föður (gildið 1) fær samtöluna 2,3. Unglingur sem á tvö heimili með tveimur settum af foreldrum og metur t.d. tengsl við föður og stjúpmóður slök (tvisvar sinnum gildið 1) en tengsl við móður og stjúpföður góð (tvisvar sinnum gildið 2) fær samtöluna 1,5. Samtölur undir 1,6 voru metnar sem merki um slök tengsl við foreldra, á meðan pær sem lentu á milli 1,6 upp í 2,2 voru túlkaðar sem góð tengsl. Allar samtölur yfir 2,2 voru skilgreindar pannig að unglingurinn hefði mjög góð tengsl við foreldra sína.

Tengsl unglinga við skólann voru metin út frá fjórum spurningum úr HBSC-könnuninni (Ársæll Arnarsson, 2019; Ársæll Arnarsson o.fl., 2020). Prjár voru fullyrðingar um kennara og áttu nemendurnir að segja hvort peir væru 1) „Mjög sammála peim“, 2) „Sammála“, 3) „Hvorki sammála né ósammála“, 4) „Ósammála“ og 5) „Mjög ósammála“. Fullyrðingarnar prjár voru svohljóðandi: a) Kennararnir taka mér eins og ég er, b) Mér finnst kennurunum vera annt um mig sem einstakling 
og c) Ég treysti kennurunum mínum mjög vel. Svarið við hverri fullyrðingu var metið pannig að peir unglingar sem voru mjög sammála voru metnir í mjög góðum tengslum við skólann og fengu gildið 3 fyrir hvert svar. Peir unglingar sem sögðust vera sammála voru metnir í góðum tengslum við skólann og hvert slíkt svar fékk gildið 2. Unglingar sem svöruðu með öðrum hætti voru hins vegar taldir í slökum tengslum og fengu pau svör gildið 1. „Hvernig líkar pér í skólanum?” var svo fjórða spurningin sem notuð var til að meta tengslin. Við henni voru gefnir fjórir svarmöguleikar: 1) „Mér líkar mjög vel í skólanum“, 2) „Mér líkar pokkalega í skólanum“, 3) „Mér líkar ekki vel í skólanum“ og 4) „Mér líkar alls ekki vel í skólanum“. Pegar pessi spurning var kóðuð fékk fyrsti svarmöguleikinn gildið 3, annar fékk gildið 2 en priðju og fjórðu svarmöguleikarnir voru kóðaðir sem 1. Kóðunin var síðan notuð pess að reikna út samtölu fyrir tengsl við skólann. Í peim útreikningi var stuðst við formúlu Andersen og Dæhlen (2017), par sem gildin frá 1 upp í 3 eru lögð saman og deilt í með fjölda svara sem í flestum tilfellum voru fjögur. Samtölur undir 1,6 voru metnar sem merki um slök tengsl við skóla á meðan pær sem lentu á milli 1,6 og 2,2 voru metnar til vitnis um góð tengsl. Allar samtölur yfir 2,2 voru skilgreindar pannig að unglingurinn hefði mjög góð tengsl við skólann sinn.

Tengsl unglinga við vini sína voru metin út frá afstöðu peirra til fjögurra fullyrðinga úr HBSC-könnuninni (Ársæll Arnarsson, 2019; Ársæll Arnarsson o.fl., 2020): a) „Vinir mínir reyna virkilega að hjálpa mér“, b) „Ég get treyst á vini mína pegar eitthvað fer úrskeiðis“, c) „Ég á vini sem deila með mér gleði og sorg“" og d) „Ég get talað við vini mína um mín vandamál“. Svarið við hverri spurningu var sett upp á sjö stiga kvarða par sem „1“ táknaði „Mjög ósammála“ og „7“ býddi „Mjög sammála“. Meðaltöl svara allra nemenda við spurningunum fjórum var reiknað og síðan endurkóðað pannig að peir sem svöruðu pessum spurningum að meðaltali með 7 á kvarðanum voru metnir í mjög góðum tengslum við vini sína og fengu gildið 3. Ef meðaltalið var á milli 5 og 6 var litið svo á að um góð vinatengsl væri að ræða og kóðað sem 2. Ef meðaltalið úr svörunum var hins vegar 4 eða lægra var pað flokkað sem slök félagstengsl og kóðað sem 1. Pessi kóðun frá 1 upp í 3 var gerð að fyrirmynd Andersen og Dæhlen (2017).

\section{Tölfræði}

Tölfræðileg úrvinnsla var framkvæmd með IBM SPSS-tölfræðiforritinu fyrir Windows (útgáfu 24.0). Lýsandi tölfræði, meðalskor og staðalfrávik fyrir samfelldar breytur og tíðni og hlutföll fyrir ósamfelldar breytur, var notuð til að lýsa gögnunum, Pearson's stuðull var notaður til að skoða fylgni milli samfelldra breyta og ópöruðu t-prófi og dreifigreiningu (ANOVA) beitt til að skoða mun á meðaltölum. Áður en t-próf og dreifigreining voru framkvæmd var kannað hvort skilyrði tölfræðigreininganna voru uppfyllt. Cronbach’s alfa var notað til að meta innri áreiðanleika gagnanna.

\section{Niðurstöður}

Alls svöruðu 2.245 nemendur í 10. bekk spurningalista HBSC-rannsóknarinnar pegar hún var lögð fyrir veturinn 2017-2018. Af peim voru 1.1084 strákar (48,4\%) en 1.111 stelpur (49,5\%). Alls skilgreindu 48 nemendur $(2,1 \%)$ kyn sitt sem „Annað“.

Mynd 1 sýnir hvernig gildi peirra 2.185 nemenda sem svöruðu öllum fullyrðingum á SWEMWBS með gildum hætti dreifðust frá 7 (lægsta gildi) upp í 35 (hæsta gildi). Eins og sjá má er dreifingin talsvert skekkt til hægri, sem bendir til pess að fleiri pátttakendur liggi ofan við miðgildið (21). Engu að si̊ður eru gildin fyrir hvert atriði listans og óháð kyni fyrir skekkju (e. skewness) og ferilris (e. kurtosis) innan pess sem telst samræmast normaldreifingu. Gildi skekkju fyrir hvert atriði listans og alla pátttakendur náði frá -0,37 til -0,58. Gildi ferliriss fyrir hvert atriði listans og alla pátttakendur náðu frá -0,36 til 0,03. Innri áreiðanleiki gagnanna reyndist vera 0,90 .

Meðalskor á SWEMWBS fyrir alla 10. bekkinga sem tóku pátt í rannsókninni var 24,8. Meðaltalið var 25,7 fyrir stráka, 24,2 fyrir stelpur en 19,8 fyrir pá einstaklinga sem skilgreindu kyn sitt með öðrum hætti en tvíkosta. Munurinn á meðalskori kynjanna á SWEMWBS var tölfræðilega marktækur $[\mathrm{F}(2,2181)=38,29, \mathrm{p}=0,000]$. 
Í rannsókninni Heilsa og líðan Íslendinga sem framkvæmd var á fullorðnum Íslendingum árið 2017 (Koushede o.fl., 2019) var meðalskor SWEMWBS fyrir allan aldurshópinn 25,4, meðalskor kvenna var 25,3 en karla 25,5. Meðalskor yngsta aldurshópsins, 18-25 ára, var 23,6 en meðalskor elsta hópsins, 65 ára og eldri, var 26,8.

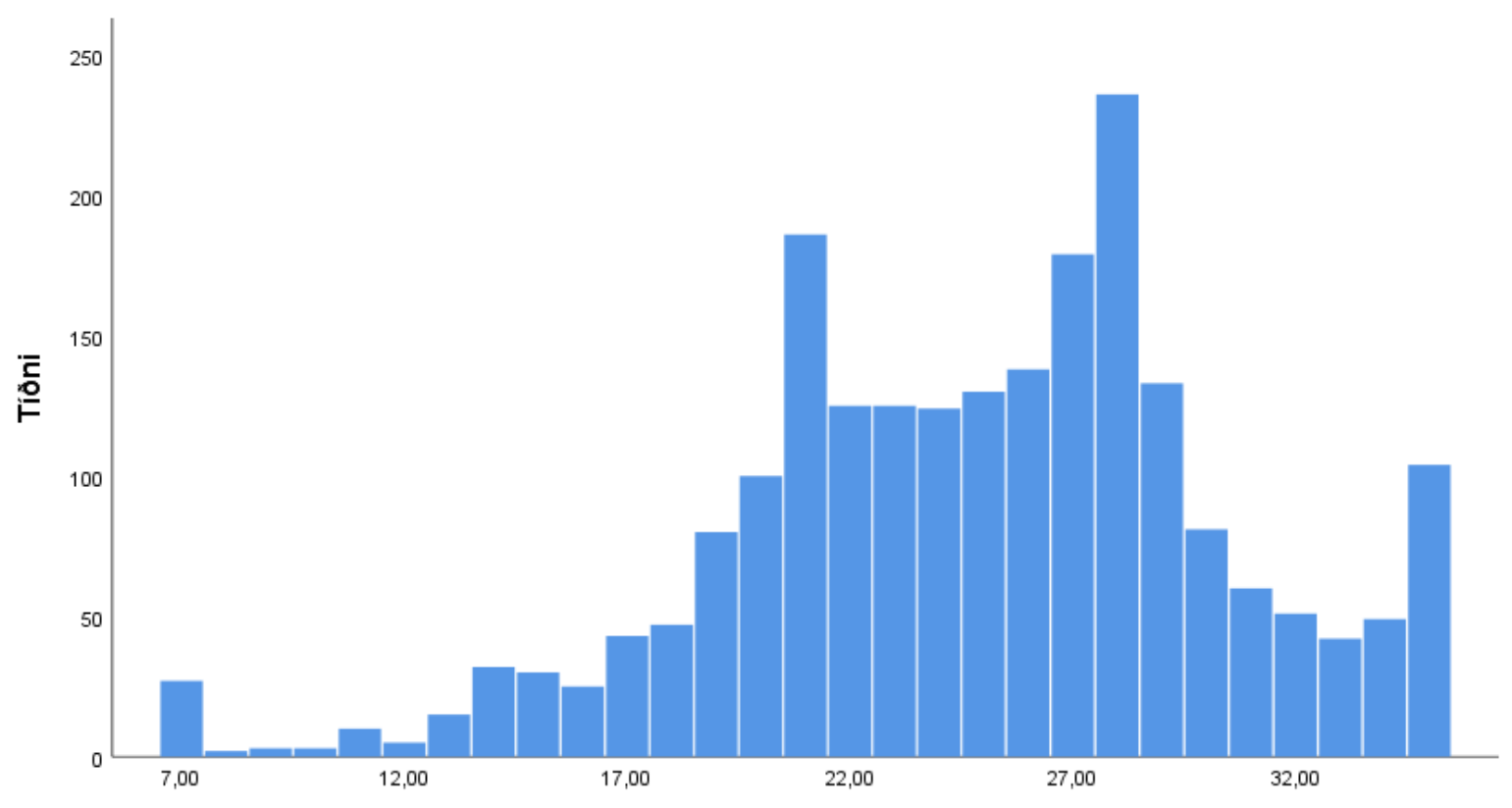

Skor á SWEMWBS

Mynd 1. Stöplarit sem sýnir dreifingu skora á SWEMWBS.

Tafla 1 sýnir fylgnistuðla milli heildarskors á SWEMWBS og einstakra atriða kvarðans en einnig milli einstakra atriða innbyrðis. Sterk fylgni milli atriða kemur ekki á óvart par sem öll atriðin eiga að mæla sama fyrirbærið. Hins vegar kemur einnig fram að pó fylgnin sé sterk pá er hún fráleitt fullkomin sem bendir til pess að atriðin séu að nema ákveðna undirpætti fyrirbærisins. Pannig sést til að mynda að atriðið sem metur pað hversu afslappað fólk er hefur talsvert veikari fylgni en hin atriðin, bæði við heildarskorið sem og önnur atriði listans.

Tafla 1. Pearson’s fylgnistuðull milli heildarskors á SWEMWBS og einstakra atriða

$\begin{array}{llllllll}1 & 2 & 3 & 4 & 5 & 6 & 7\end{array}$

1. SWEMWBS heildarskor

2. Ég hef verið bjartsýn/n um framtíðina $\quad 0,81^{* *}$

3. Mér hefur pótt ég gera gagn $\quad 0,84^{* *} 0,73^{* *}$

4. Ég hef verið afslöppuð/afslappaður $\quad 0,67^{* *} 0,42^{* *} 0,46^{* *}$

5. Mér hefur gengið vel að takast á við vandamál $0,85^{* *} 0,62^{* *} 0,67^{* *} 0,50^{* *}$

6. Ég hef hugsað skýrt $\quad 0,84^{* *} 0,60^{* *} 0,63^{* *} 0,47^{* *} 0,72^{* *}$

7. Mér hefur fundist ég vera náin/n öðrum $0,77^{* *} 0,57^{* *} 0,58^{* *} 0,44^{* *} 0.57^{* *} 0,60^{* *}$

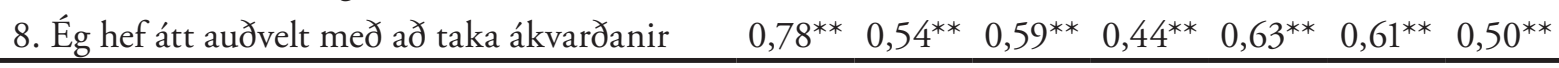

${ }^{*}$ Marktækt miðað við 0,05 (tvíhliða)

**Marktækt miðað við 0,01 (tvíhliða) 
Í Töflu 2 sést fylgni milli heildarskors á SWEMWBS annars vegar og einstaka atriða hans hins vegar við útkomu úr sjónhendingarkvarða Cantrils. Mesta fylgnin sést milli heildarskorsins og Cantril-kvarðans eða 0,60. Lægstu fylgnina hefur Cantril-kvarðinn hins vegar við spurninguna um hvort viðkomandi upplifi sig afslappaðan $(0,31)$. Tafla 2 sýnir einnig fylgni milli heildarskors á SWEMWBS annars vegar og einstaka atriða hans hins vegar við mat á eigin heilsu og HBSC Symptom Check listann. Fylgnin var öll tölfræðilega marktæk en talsvert lægri en fylgni Cantril-kvarðans við SWEMWBS.

Fylgnin milli sállíkamlegra einkenna (HBSC Symptom Checklist) og SWEMWBS er sýnd í premur dálkum í Töflu 2, fyrst fyrir öll einkennin í heild, næst fyrir einkenni sem frekar tengjast sálrænum páttum og að lokum fyrir einkenni sem frekar tengjast líkamlegum páttum.

Tafla 2. Pearson’s fylgnistuðull milli heildarskors og einstakra atriða á SWEMWBS og Cantril-kvarðans, mats á eigin heilsu og HBSC Symptom Checklist.

\begin{tabular}{lccccc}
\hline & & \multicolumn{4}{c}{ HBSC Symptom Checklist } \\
& Cantril & Heilsa & Heild & Sálræn & Líkamleg \\
\hline SWEMWBS heildarskor & $0,60^{* *}$ & $0,45^{* *}$ & $0,49^{* *}$ & $0,52^{* *}$ & $0,25^{* *}$ \\
1. Ég hef verið bjartsýn/n um framtíðina & $0,50^{* *}$ & $0,38^{* *}$ & $0,38^{* *}$ & $0,45^{* *}$ & $0,19^{* *}$ \\
2. Mér hefur pótt ég gera gagn & $0,55^{* *}$ & $0,41^{* *}$ & $0,41^{* *}$ & $0,45^{* *}$ & $0,19^{* *}$ \\
3. Ég hef verið afslöppuð/afslappaður & $0,31^{* *}$ & $0,20^{* *}$ & $0,29^{* *}$ & $0,28^{* *}$ & $0,17^{* *}$ \\
4. Mér hefur gengið vel að takast á við vandamál & $0,54^{* *}$ & $0,38^{* *}$ & $0,44^{* *}$ & $0,47^{* *}$ & $0,23^{* *}$ \\
5. Ég hef hugsað skýrt & $0,51^{* *}$ & $0,38^{* *}$ & $0,44^{* *}$ & $0,44^{* *}$ & $0,23^{* *}$ \\
6. Mér hefur fundist ég vera náin/n öðrum & $0,43^{* *}$ & $0,31^{* *}$ & $0,30^{* *}$ & $0,34^{* *}$ & $0,15^{* *}$ \\
7. Ég hef átt auðvelt með að taka ákvarðanir & $0,45^{* *}$ & $0,36^{* *}$ & $0,41^{* *}$ & $0,42^{* *}$ & $0,20^{* *}$ \\
\hline
\end{tabular}

*Marktækt miðað við 0,05 (tvíhliða)

**Marktækt miðað við 0,01 (tvíhliða)

Í lokahluta rannsóknarinnar var skoðað hvernig bakgrunnsbreytur, sem vitað er að hafa sterk áhrif á heilsu og líðan unglinga, höfðu áhrif á útkomu peirra á SWEMWBS. Í Töflu 3 má sjá að munurinn á meðalskori pátttakenda á SWEMWBS eftir pví hvort peir voru fæddir á Íslandi eða ekki, var tölfræðilega marktækur $(\mathrm{p}<0,01)$. Athygli vekur hversu peir pátttakendur sem eru fæddir í öðru landi og skilgreina kyn sitt sem „Annað“ skora miklu lægra en aðrir hópar. Tafla 3 sýnir einnig tengsl fjárhagsstöðu fjölskyldunnar við meðalskor á SWEMWBS. Nær undantekningarlaust virðist slakari fjárhagsstaða tengjast lakari andlegri líðan $[\mathrm{F}(4,2154)=39,92, \mathrm{p}=0,000]$. Petta virðist eiga við óháð kyni. Einstaka meðalskor ber pó að túlka varfærnislega, par sem sum peirra byggja á afar fáum svarendum. Tengsl unglinga við foreldra sína hafði einnig marktæk áhrif á meðalskor peirra á SWEMWBS, par sem betri tengslum fylgdi betri líłan $[\mathrm{F}(2,2157)=202,41, \mathrm{p}=0,000]$. Afar svipað mynstur mátti sjá pegar tengsl unglinga við skólann $[\mathrm{F}(2,2181)=199,85, \mathrm{p}=0,000]$ og vini $[\mathrm{F}(2,2137)=94,63, \mathrm{p}=0,000]$ voru skoðuð. 
Tafla 3. Áhrif bakgrunnsbreyta á útkomu nemenda í 10. bekk á SWEMWBS eftir kyni.

\begin{tabular}{|c|c|c|c|c|c|}
\hline & & \multicolumn{4}{|c|}{ Meðalskor á SWEMWBS (N) } \\
\hline & & Strákar & Stelpur & Annað & Heild \\
\hline \multicolumn{6}{|l|}{ Fæðingarland } \\
\hline & Ísland & $25,9(949)$ & $24,3(969)$ & $23,4(23)$ & $25,1(1.941)^{*}$ \\
\hline & Annað land & $23,9(94)$ & $23,3(129)$ & $14,9(17)$ & $23,0(240)^{*}$ \\
\hline \multicolumn{6}{|c|}{ Fjárhagsstaða fjölskyldu } \\
\hline & Mjög góð & $27,7(362)$ & $25,7(325)$ & $22,4(9)$ & $26,7(696)^{*}$ \\
\hline & Góð & $25,0(419)$ & $24,3(494)$ & $23,5(13)$ & $24,6(926)$ \\
\hline & Miðlungs & $24,5(220)$ & $22,7(238)$ & $17,7(11)$ & $23,4(469)$ \\
\hline & Slæm & $23,7(20)$ & $19,5(31)$ & - & $21,2(51)$ \\
\hline & Mjög slæm & $24,5(8)$ & $17,5(4)$ & $11,8(5)$ & $19,1(17)^{*}$ \\
\hline \multicolumn{6}{|c|}{ Tengsl við foreldra } \\
\hline & Mjög góð & $27,7(483)$ & $26,6(448)$ & $23,8(12)$ & $27,1(943)^{*}$ \\
\hline & Góð & $25,0(323)$ & $23,7(323)$ & $23,9(12)$ & $24,4(658)$ \\
\hline & Slök & $22,9(223)$ & $21,2(2)$ & $13,6(14)$ & $21,7(559)^{*}$ \\
\hline \multicolumn{6}{|c|}{ Tengsl við skóla } \\
\hline & Mjög góð & $27,8(473)$ & $26,5(486)$ & $25,7(11)$ & $27,1(970)^{*}$ \\
\hline & Góð & $25,0(300)$ & $23,5(317)$ & $20,4(10)$ & $24,2(627)$ \\
\hline & Slök & $23,0(272)$ & $21,1(296)$ & $16,0(19)$ & $21,8(587)^{*}$ \\
\hline \multicolumn{6}{|l|}{ Tengsl við vini } \\
\hline & Mjög góð & $28,1(294)$ & $26,3(466)$ & $22,1(10)$ & $26,9(770)^{*}$ \\
\hline & Góð & $25,7(390)$ & $22,9(365)$ & $23,0(6)$ & $24,3(761)$ \\
\hline & Slök & 24,1 (329) & $22,3(260)$ & $18,8(20)$ & $23,1(609)^{*}$ \\
\hline
\end{tabular}

${ }^{*}$ Marktækur munur $\mathrm{p}<0,01$

\section{Umræða}

Niðurstöður pessarar rannsóknar benda til að SWEMWBS sé góður kostur og mikilvæg viðbót sem mælitæki fyrir andlega líðan unglinga á Íslandi. Innri áreiðanleiki gangnanna mældist hár líkt og hann hefur mælst í öðrum rannsóknum (Haver o.fl., 2015; Ringal o.fl., 2018). Pó dreifingin sé skekkt er pað innan eðlilegra marka. Meðalskor á SWEMWBS fyrir alla 10. bekkinga sem tóku pátt í rannsókninni var örlítið lægri en meðal fullorðinna í rannsókninni Heilsa og líðan Íslendinga sem framkvæmd var á 18 ára og eldri árið 2017 (Koushede o.fl., 2019). Pess ber pó að geta að pegar aldurshóparnir í peirri rannsókn voru greindir í sundur, kom í ljós að meðalskorið jókst með hækkandi aldri. Enginn stórvægilegur munur reyndist hins vegar á svörum karla og kvenna í Heilsu og líðan Íslendinga. Í okkar gögnum kemur hins vegar fram marktækur munur eftir kynjum, lægst hjá peim sem skilgreindu kyn sitt sem annað en karl eða kona. Pessi priðji hópur var ekki til staðar í Heilsu og líðan, en útkoma hans í HBSC-rannsókninni er undantekningarlaust mun lakari en stelpna og stráka (Ársæll Arnarsson o.fl., 2020). Hugsanleg skýring á pví af hverju lítill kynjamunur var á meðalskori SWEMWBS fullorðinna einstaklinga en kynjamunur fannst meðal 10. bekkinga gæti tengst pví að unglingsstúlkur mælast iðulega með meiri kvíða og punglyndi en drengir á sama aldri (Sunna Gestsdóttir o.fl., 2015). Oft dregur úr kvíða og punglyndi stúlkna pegar pær eldast (Henderson o.fl., 1998; Sunna Gestsdóttir o.fl., 2015) og pví mætti leiða líkur að pví að andleg líðan kvenna verði jákvæðari pegar á fullorðinsárin kemur. 
Stærstu kostirnir við pá rannsókn sem hér er kynnt eru annars vegar úrtaksstærðin og hins vegar pau mælitæki sem hægt er að bera SWEMWBS saman við. Pað getur verið vísbending um hugtakaréttmæti. Pannig sést nokkur fylgni milli heildarskors SWEMWBS og einstakra atriða hans við lífsánægjukvarða Cantrils. Fylgnin er samt ekki pað kröftug að um sé að ræða mælingar á nákvæmlega sama fyrirbærinu. Svipaða sögu er að segja um fylgnina við mat á eigin heilsu. Рað verður pó að hafa í huga að í peim útreikningum var fjögurra punkta raðkvarða umbreytt í jafnbilakvarða og pví ber að túlka pá útreikninga af varfærni. Eins og tilgáta okkar gerði ráð fyrir, sýndi SWEMWBS sterkari fylgni við sálrænu en líkamlegu einkennin í HBSC-listanum. Dví mætti leiða að pví líkum að SWEMWBS sé að meta jákvæða hlið geðheilsu frekar en vanlíðan. Í kjölfarið verður pví hægt að kanna ítarlegar hvaða pættir tengjast vellíðan og möguleiki er pá fyrir hendi að efla slíka pætti sérstaklega.

Hin hliðin á framantöldum kostum er að aukinn fjöldi pátttakenda eykur alltaf áreiðanleika. Fjöldinn gerir pað líka að verkum að nær allur munur eða fylgni sem kemur fram er afar tölfræðilega marktækur. Pað leggur pá byrði á herðar höfunda og lesenda að hafa í huga að pó tengsl nái marktækni pýðir pað ekki endilega að pau séu merkingarbær, p.e.a.s. pó svo að um tölfræðilega marktækni sé að ræða pá er ekki víst að klínísk marktækni náist.

Afar mikilvægt er að geta metið og fylgst með andlegri líðan íslenskra unglinga án pess að pað sé alltaf undir klínískum formerkjum. Mælitæki eins og pað sem hér er til umfjöllunar getur veitt breiðari sýn á andlega líðan með pví að horfa til jákvæðari pátta í andlegri heilsu einstaklingsins. Með SWEMWBS er hægt að skoða bæði eudaímoníska og hedóníska pætti vellíðanar, sem skipta ekki síður máli en klínískir pættir andlegrar líðanar. Flestir vísindamenn eru peirrar skoðunar að undirstöður andlegrar heilsu einstaklingsins séu lagðar á unga aldri (Goodman o.fl., 2011). Forvarnir og inngrip purfa pví að koma snemma til sögunnar. Pannig hefur til dæmis tekist að sýna fram á að foreldrapjálfun geti haft áhrif á vellíðan og andlega heilsu afkvæmanna í gegnum æviskeiðið (Stewart-Brown og Schrader-McMillan, 2011). Pá hefur grunnskólinn einnig í sífellt meiri mæli verið notaður til pess að koma í kring jákvæðum breytingum á andlegri heilsu unglinga (O'Connor o.fl., 2015). Mörg slík inngrip hafa einnig sýnt ágæt áhrif á félagslega og tilfinningalega hæfni (Durlak o.fl., 2011). Jákvæðu áhrifin sem pannig fást fram hafa samt ekki einvörðungu pýðingu á pessu sérstaka æviskeiði, heldur hjálpa pau einstaklingnum að glíma við áskoranir fullorðinsáranna (Schulenberg o.fl., 2004). SWEMW BS getur reynst gagnlegur í framtíðinni til pess að meta árangur af margs konar inngripum, verkefnum og stefnumótandi aðgerðum með ódýrum og pægilegum hætti.

Mikil umræða hefur farið fram hér á landi og annars staðar í heiminum um fjölgun greininga á geðrænum vanda meðal peirrar kynslóðar sem nú er að vaxa úr grasi. Fjöldi rannsókna um petta efni hefur birst og stungið hefur verið upp á ýmiss konar inngripum og forvörnum til úrbóta. Alpjóðlegar rannsóknir hafa nánast allar sýnt fram á aukningu í greiningum og meðferðum geðraskana (Collishaw, 2015) og hérlendis sýna tölur hrakandi geðheilsu meðal ungs fólks (Sigrún Daníelsdóttir o.fl., 2017), einkum stúlkna (Margrét Lilja Guðmundsdóttir o.fl., 2016).

Pegar dreifing SWEMWBS-skora var skoðuð með hliðsjón af öðrum bakgrunnsbreytum en kyni, kom í ljós að peir sem fæddir voru annars staðar en á Íslandi skoruðu lægra. Einnig hafði fjárhagsstaða fjölskyldu marktæk neikvæð tengsl við SWEMWBS. Betri tengsl við fjölskyldu tengdust hins vegar betri niðurstöðu á kvarðanum. Eru pessar niðurstöður í samræmi við niðurstöður nýlegrar rannsóknar Ársæls Arnarssonar (2019) á punglyndi meðal 10. bekkinga. Par kom í ljós að mjög slæm fjárhagsstaða fjölskyldunnar 25-faldaði líkurnar á að unglingar fyndu fyrir depurð á hverjum degi. Peir unglingar sem skilgreindu kyn sitt sem „Annað“ en strákur eða stelpa, voru átta sinnum líklegri en jafnaldrar peirra til að finna fyrir depurð daglega. Fimmföldun á áhættu sást meðal peirra sem áttu slök tengsl við foreldra eða við skóla. Slök vinatengsl prefölduðu líkurnar. Aðrir pættir sem um pað bil tvöfölduðu líkurnar voru fæðingarland unglings og foreldra hans. Aðrir neikvæðir lífsstílspættir höfðu sterk tengsl við aukið punglyndi, t.d. svefnskortur, áfengisneysla og reykingar svo einhverjir séu nefndir (Ársæll Arnarsson, 2019). Pað er pví ljóst að lakari andleg heilsa íslenskra unglinga á sér fjölpættar skýringar. Í peim öldudal sem nú virðist ríkja í andlegri heilsu íslenskra unglinga er 
áríðandi að verja fjármunum til inngripa og rannsókna með sem allra bestum hætti. Fjárfestingar í heilsueflingu, forvörnum og snemmtækri íhlutun munu skila sér margfalt til baka, svo fremi sem notast er við gagnreyndar aðferðir (Forsman o.fl., 2015). Sömuleiðis er áríðandi að skoða hvernig peir pættir sem hafa áhrif á útkomu eins og depurð verka á andlega líðan eins og hún mælist með SWEMWBS.

Jákvæðar hliðar andlegrar heilsu unglinga purfa einnig að vera ígrundaðar betur. Раð er pví ekki hvað síst mikilvægt að kortleggja hvaða pættir tengjast jákvæðri líðan eins og gert er í pessari rannsókn svo hægt sé að efla pá sérstaklega. Rannsókn Hawkins og félaga (2012) sýndi að jákvæð próun á andlegri líðan seinni hluta unglingsáranna spáði fyrir um bætta andlega og líkamlega heilsu, betri tengsl við vini og minni líkur á andfélagslegri hegðun pegar pátttakendur höfðu náð 23-24 ára aldri. Góð andleg heilsa tekur pó ekki aðeins til líðanar einstaklinga heldur líka til pátttöku peirra í samfélaginu (Lerner o.fl., 2005). Rannsókn O’Connors og félaga (2017) sýndi til dæmis fram á að jákvæð andleg heilsa spáði fyrir um meiri borgaralega pátttöku á fullorðinsárum, sem sýnir enn og aftur fram á hag samfélagsins alls. Notkun SWEMWBS er fýsilegur kostur við mat á andlegri líðan ungmenna par sem áhersla er lögð á jákvæða hlið geðheilsu.

\section{Mental well-being among Icelandic adolescents in the 10th grade measured by a short version of the Warwick-Edinburgh Mental Well-being Scale}

The importance of adolescents' health and well-being has been an increasing issue in both public discourse and scientific research over the past years. In many international studies, a general trend of declining mental health in this age group has been observed. This has been met with a call to arms by the scientific community, emphasising more rigorous studies and implementation of evidence-based interventions and policies. However, given the predominant clinical emphasis of studies in this field, it is important to contemplate what mental health means in a more holistic sense. The World Health Organization (WHO) defines it as a state of well-being, in which people are aware of their own abilities, can successfully deal with the stressors of daily life, can succeed in their work and contribute to society. This definition emphasises that mental health is not merely the absence of disease or feeling good. Rather, it centres around the age-old question of the good life, that has been around from the time of Aristotle to modern day positive psychology; that is, whether it would be more beneficial to focus on the momentary joys of life (hedonia), or whether it is more important to do something worthwhile (eudaimonia). The hedonic aspect focuses on being happy, experience pleasure, and freedom from discomfort. The eudaimonic view is more centred on human possibilities, meaning and self-discovery. In the international Health Behaviour in School-Aged Children Study (HBSC), the largest of its kind in the world, mental wellbeing has been measured by various means. Growing concerns about the deterioration in mental health among adolescents led researchers from the Nordic countries to include more variables dealing with this topic in the 2017/2018 wave of the study, including a shorter version of the Warwick-Edinburgh Mental Well-Being Scale (SWEMWBS). This scale includes 7 items that are phrased in a positive manner and target positive aspects of mental health. Previous studies, including some within adolescent samples, have shown it to be reliable and valid. A total of 2,245 Icelandic students answered the questionnaire in 2017-2018. Of those, 1,1084 were boys (48.4\%), 1,111 were girls (49.5\%) and $48(2.1 \%)$ defined their gender as "Other". The mean score on the SWEMWBS for all participants was 24.8; 25.7 for boys, 24.2 for girls and19.8 for those that defined their gender as "Other". In all analyses, the last-mentioned group had much worse scores than boys and girls. Also interesting in terms of gender was the fact that Icelandic boys scored significantly higher than girls on the SWEMWBS in all our analyses. The scores fell within the range of normal distribution as estimated by skewness and kurtosis values. A strong correlation 
was found between both the total score on SWEMWBS and its individual items, and other measurements that had previously been used to assess wellbeing in the HBSC-study, such as the Cantril scale, self-rated health and the HBSC Symptom Checklist. It was clear, though, that the SWEMWBS scores did not represent exactly the same phenomena as the previously used measures. Background variables such as family financial status, country of birth, and relations with parents, school and friends, all influenced the distribution of SWEMWBS scores. Adolescents coming from poorer families, born outside of Iceland, and with worse relations with parents, school and friends, scored consistently and significantly lower on the SWEMWBS than their peers. We conclude that the scores from the current study of the shorter version of the Warwick-Edinburgh Mental Well-Being Scale, are a valid and valuable addition to research measures focusing on adolescent health.

Key words: SWEMWBS, Warwick-Edinburgh, adolescents, HBSC.

\section{Um höfunda}

Ársæll Arnarsson (arsaell@hi.is) er prófessor í tómstunda- og félagsmálafræði við Menntavísindasvið Háskóla Îslands. Hann lauk BA-prófi í sálfræði 1993, MS-gráðu í heilbrigðisvísindum 1997 og PhD-gráðu í líf- og læknavísindum frá HÍ árið 2009. Síðastliðinn áratug hafa rannsóknir hans aðallega beinst að heilsufari og líðan unglinga.

Sunna Gestsdóttir (gsunnag@hi.is) er sálfræðingur og lektor í heilsueflingu við Menntavísindasvið Háskóla Íslands. Hún lauk BA-prófi í sálfræði 2007, MS-gráðu í heilbrigðisvísindum 2010, PhD-gráðu í íprótta- og heilsufræði árið 2016 og MS-gráðu í klínískri sálfræði 2020. Helstu áherslur í rannsóknum undanfarin ár hafa verið andleg líðan og líkamlegt atgervi ungs fólks.

\section{About the authors}

Ársæll Arnarsson (arsaell@hi.is) is a professor of leisure studies at the University of Iceland School of Education. He completed a BA degree in psychology in 1993, an MSc degree in health sciences in 1997 and a PhD in biomedical sciences in 2009 from the University of Iceland. For the past decade his research has focused on the health and well-being of adolescents.

Sunna Gestsdóttir (gsunnag@hi.is) is a psychologist and assistant professor at the University of Iceland School of Education. Her education is a BA in psychology 2007, an MSc in health sciences 2010, a PhD in sport and health sciences 2016, and an MSc in clinical psychology 2020. Her research focus has been on mental and physical health in adolescents and young adults. 


\section{Heimildir}

Andersen, P. L. og Dæhlen, M. (2017). Sosiale relasjoner i ungdomstida - Identifisering og beskrivelse av ungdom med svake relasjoner til foreldre, skole og venner. Nova. http://hdl.handle.net/20.500.12199/5114

Ársæll Arnarsson. (2019). Depurð meðal skólabarna á Íslandi. Sérrit Netlu 2019-Alpjóðlegar menntakannanir. https://doi.org/10.24270/serritnetla.2019.30

Ársæll Arnarsson, Sigrún Daníelsdóttir og Rafn Jónsson. (2020). Félagstengsl íslenskra unglinga. Embatti landlaknis. https://www.landlaeknir.is/servlet/file/store93/item41614/F\%C3\%A9lagstengsl\%20barna\%20 og\%20ungmenna_LOK.pdf

Bjorner. J. B. (1996). Self-rated health: A useful concept in research, prevention and clinical medicine. Swedish Council for Planning and Coordination of Research (Forskningsrådsnämnden, FRN).

Cantril, H. (1965). The pattern of human concern. Rutgers University Press.

Cavallo, F., Zambon, A., Borraccino, A., Raven-Sieberer, U., Torsheim, T., Lemma, P. og HBSC Positive Health Group. (2006). Girls growing through adolescence have a higher risk of poor health. Quality of Life Research, 15, 1577-1585. https://doi.org/10.1007/s11136-006-0037-5

Collishaw, S. (2015). Annual research review: Secular trends in child and adolescent mental health. Journal of Child Psychology and Psychiatry, 56(3), 370-393. https://doi.org/10.1111/jcpp.12372

Dóra Guðrún Guðmundsdóttir. (2011). Positive psychology and public health. Í R. B. Diener (ritstjóri), Positive psychology as social change (bls. 109-122). Springer.

Durlak, J. A., Weissberg, R. P., Dymnicki, A. B., Taylor, R. D. og Schellinger, K. B. (2011). The impact of enhancing students' social and emotional learning: A meta-analysis of school-based universal interventions. Child Development, 82(1), 405-432. https://doi.org/10.1111/j.1467-8624.2010.01564.x

Eriksson, C., Ársæll Arnarsson, Damsgaard, M. T., Potrebny, T., Souminen, S., Torsheim, T. og Due, P. (2019). Building knowledge of adolescent mental health in the Nordic countries. Nordic Welfare Research, 4(2), 43-53. https://doi.org/10.18261/issn.2464-4161-2019-02-02

Evans, D. L., Foa, E. B., Gur, R. E., Hendin, R., O’Brien, C. P., Seligman, M. E. P. og Walsh, B. T. (ritstjórar). (2005). Treating and preventing adolescent mental health disorders: What we know and what we don't know: $A$ research agenda for improving the mental health of our youth. Oxford University Press.

Forsman, A. K., Wahlbeck, K., Aarø, L. E., Alonso, J., Barry, M. M., Brunn, M., Cardoso, G., Cattan, M., de Girolamo, G., Eberhard-Gran, M., Evans-Lacko, S., Fiorillo, A., Hansson, L., Haro, J. M., Hazo, J.-B., Hegerl, U., Katschnig, H., Knappe, S., Luciano, M., ... Värnik, A. (2015). Research priorities for public mental health in Europe: Recommendations of the ROAMER project. European Journal of Public Health, 25(2), 249-254. https://https://doi.org/10.1093/eurpub/cku232

Goodman, A., Joyce, R. og Smith, J. P. (2011). The long shadow cast by childhood physical and mental problems on adult life. Proceedings of the National Academy of Sciences, 108(15), 6032-6037. https://doi. org/10.1073/pnas.1016970108

Greenspoon, P. J. og Saklofske, D. H. (2001). Toward an integration of subjective well-being and psychopathology. Social Indicators Research, 54, 81-108. https://doi.org/10.1023/A:1007219227883

Haver, A., Akerjordet, K., Caputi, P., Furunes, T. og Magee, C. (2015). Measuring mental well-being: A validation of the Short Warwick-Edinburgh Mental well-being scale in Norwegian and Swedish. Scandinavian Journal of Public Health, 43(7), 721-727. https://doi.org/10.1177/1403494815588862

Hawkins, M. T., Villagonzalo, K. A., Sanson, A. V., Toumbourou, J. W., Letcher, P. og Olsson, C. A. (2012). Associations between positive development in late adolescence and social, health, and behavioral outcomes in young adulthood. Journal of Adult Development, 19, 88-99. https://doi.org/10.1007/s10804-011-9137-8

Henderson, A. S., Jorm, A. F., Korten, A. E., Jacomb, P., Christensen, H. og Rodgers, B. (1998). Symptoms of depression and anxiety during adult life: Evidence for a decline in prevalence with age. Psychological Medicine, 28(6), 1321-1328.

Inchley, J., Currie, D., Budisavljevic, S., Torsheim, T., Jåstad, A., Cosma, A., Kelly, C., Ársæll Már Arnarsson, Barnekow, V. og Weber, M. M. (2020). Spotlight on adolescent health and well-being: Findings from the 2017/18 Health Behaviour in School-aged Children (HBSC) survey in Europe and Canada. Volume 1: Key findings. World Health Organization. 
Kelleher, C. C., Tay, J. og Gabhainn, S. N. (2007). Influence on self-rated health of socio-demographic, lifestyle and affluence factors: An analysis of the Irish and international Health behaviours among school-aged children (HBSC) datasets 1998. Irish Medical Journal, 100(suppl.), 43-46. PMID: 17955702

Keyes, C. (2006). Mental health in adolescence: Is America's youth flourishing? American Journal of Orthopsychiatry, 76(3), 395-402. https://doi.org/10.1037/0002-9432.76.3.395

Koushede, V., Lasgaard, M., Hinrichsen, C., Meilstrup, C., Nielsen, L., Boe Rayce, S., Torres-Sahli, M., Dóra Guðrún Guðmundsdóttir, Stewart-Brown, S. og Santini, Z. I. (2019). Measuring mental well-being in Denmark: Validation of the original and short version of the Warwick-Edinburgh Mental well-being scale (WEMWBS and SWEMWBS) and cross-cultural comparison across four European settings. Psychiatry Research, 271, 502-509. https://doi.org/10.1016/j.psychres.2018.12.003

Lerner, R., Lerner, J., Almerigi, J., Theokas, C., Phelps, E., Gestsdottir, S. og Ma, L. (2005). Positive youth development, participation in community youth development programs, and community contributions of fifth-grade adolescents findings from the first wave of the 4- $\mathrm{H}$ study of Positive Youth Development. The Journal of Early Adolescence, 25(1), 17-71. https://doi.org/10.1177/0272431604272461

Margrét Lilja Guðmundsdóttir, Hrefna Pálsdóttir, Jón Sigfússon, Ingibjörg Eva Pórisdóttir, Erla María Tölgyes, Álfgeir Logi Kristjánsson og Inga Dóra Sigfúsdóttir. (2016). Ungt fólk 2016: 8.-10. bekkur. Rannsóknir og greining; Mennta- og menningarmálaráðuneytið.

McKay, M. T. og Andretta, J. R. (2017). Evidence for the psychometric validity, internal consistency and measurement invariance of Warwick Edinburgh Mental well-being scale scores in Scottish and Irish adolescents. Psychiatry Research, 255, 382-386. https://doi.org/10.1016/j.psychres.2017.06.071

Mikkelsson, M., Salminen, J. og Kautiainen, H. (1997). Non-specific musculoskeletal pain in preadolescents: Prevalence and 1-year persistence. Pain, 73(1), 29-35. https://doi.org/10.1016/s0304-3959(97)00073-0

O'Connor, M., Sanson, A., Toumbourou, J., Hawkins, M., Letcher, P., Williams, P. og Olsson, C. (2015). Positive development and resilience in emerging adulthood. Í J. Arnett (ritstjóri), The Oxford handbook of emerging adulthood (bls. 601-614). Oxford University Press.

O’Connor, M., Sanson, A. V., Toumbourou, J. W., Norrish, J. og Olsson, C. A. (2017). Does positive mental health in adolescence longitudinally predict healthy transitions in young adulthood? Journal of Happiness Studies, 18(1), 177-198. https://doi.org/10.1007/s10902-016-9723-3

Paus, T., Keshavan, M. og Giedd, J. N. (2008). Why do many psychiatric disorders emerge during adolescence? Nature Reviews Neuroscience, 9(12), 947-957. https://doi.org/10.1038/nrn2513

Ravens-Sieberer, U., Torsheim, T., Hetland, J., Vollebergh, W., Cavallo, F., Jericek, H., Alikasifoglu, M., Välimaa, R., Ottova, V., Erhart, M. og HBSC Positive Health Focus Group. (2009). Subjective health, symptom load and quality of life of children and adolescents in Europe. International Journal of Public Health, 54(2), 151-159. https://doi.org/10.1007/s00038-009-5406-8

Ringdal, R., Bradley Eilertsen, M. E., Bjørnsen, H. N., Espnes, G. A. og Moksnes, U. K. (2018). Validation of two versions of the Warwick-Edinburgh Mental well-being scale among Norwegian adolescents. Scandinavian Journal of Public Health, 46(7), 718-725.

Ryan, M. R. og Deci, L. E. (2001). On happiness and human potentials: A review of research on hedonic and eudaimonic well-being. Annual Review of Psychology, 52, 141-166. https://doi.org/10.1146/annurev. psych.52.1.141

Ryff, C. D. og Singer, B. (1998). The contours of positive human health. Psychological Inquiry, 9(1), 1-28. https://psycnet.apa.org/doi/10.1207/s15327965pli0901_1

Sawyer, M. G., Miller-Lewis, L. R. og Clark, J. (2007). The mental health of 13-17 year-olds in Australia: Findings from the National survey of mental health and well-being. Journal of Youth and Adolescence, 36(2), 185-194. https://doi.org/10.1007/s10964-006-9122-x

Schulenberg, J., Bryant, A. og O'Malley, P. (2004). Taking hold of some kind of life: How developmental tasks relate to trajectories of well-being during the transition to adulthood. Development and Psychopathology, 16(4), 1119-1140. https://doi.org/10.1017/s0954579404040167

Sigrún Daníelsdóttir, Védís Helga Eiríksdóttir og Salbjörg Bjarnadóttir. (2017). Geðheilbrigði ungs fólks á Íslandi fer hrakandi. Talnabrunnur Embattis landlaknis, 11(6), 1-4. https://www.landlaeknir.is/servlet/file/ store93/item32745/Talnabrunnur_Agust_2017.pdf 
Smith, O. R. F., Alves, D. E., Knapstad, M., Haug, E. og Aarø, L. E. (2017). Measuring mental well-being in Norway: Validation of the Warwick-Edinburgh Mental well-being scale (WEMWBS). BMC Psychiatry, 17(1), 182. https://doi.org/10.1186/s12888-017-1343-x

Stewart-Brown, S. L. og Schrader-McMillan, A. (2011). Parenting for mental health: What does the evidence say we need to do? Report of Workpackage 2 of the DataPrev project. Health Promotion International, 26(suppl. 1), i10-28. https://doi.org/10.1093/heapro/dar056

Stewart-Brown, S. L., Tennant, A. og Tennant, R. (2009). Internal construct validity of the Warwick-Edinburgh Mental well-being scale (WEMWBS): A Rasch analysis using data from the Scottish health education population survey. Health and Quality of Life Outcomes, 7, 15. https://doi.org/10.1186/1477-7525-7-15

Suldo, S. M. og Shaffer, E. J. (2008). Looking beyond psychopathology: The dual-factor model of mental health in youth. School Psychology Review, 37(1), 52-68. https://doi.org/10.1080/02796015.2008.12087908

Suldo, S. M., Thalji, A. og Ferron, J. (2011). Longitudinal academic outcomes predicted by early adolescents' subjective well-being, psychopathology, and mental health status yielded from a dual factor model. Journal of Positive Psychology, 6, 17-30. https://doi.org/10.1080/17439760.2010.536774

Sunna Gestsdóttir, Ársæll Arnarsson, Kristján Magnússon, Sigurbjörn Árni Arngrímsson, Pórarinn Sveinsson og Erlingur Jóhannsson. (2015). Gender differences in development of mental well-being from adolescence to young adulthood: An eight-year follow-up study. Scandinavian Journal of Public Health, 43(3), 269-275. https://doi.org/10.1177/1403494815569864

Tennant, R., Joseph, S. og Stewart-Brown, S. (2007). The Affectometer 2: A measure of positive mental health in UK populations. Quality of Life Research, 16, 687-95. https://doi.org/10.1007/s11136-006-9145-5

Torsheim, T., Nygren, J. M., Rasmussen, M., Ársæll M. Arnarsson, Bendtsen, P., Schnohr, C. W., Nielsen, L. og Nyholm, M. (2018). Social inequalities in self-rated health: A comparative cross-national study among 32,560 Nordic adolescents. Scandinavian Journal of Public Health, 46(1), 150-156. https://doi. org/10.1177/1403494817734733

Trousselard, M., Steiler, D., Dutheil, F., Claverie, D., Canini, F., Fenouillet, F., Naughton, G., Stewart-Brown, S. og Franck, N. (2016). Validation of the Warwick-Edinburgh Mental well-being scale (WEMWBS) in French psychiatric and general populations. Psychiatry Research, 245, 282-290. https://doi.org/10.1016/j. psychres.2016.08.050

Unnur Jónsdóttir. (2018). Áhrif efnahagshrunsins 2008 á andlega líðan og efnahagsstöðu fólks með og án geðræns vanda [meistararitgerð, Háskóli Íslands]. Skemman. http://hdl.handle.net/1946/31857

WHO. (2004). Promoting mental health: Concept emerging evidence and practice. Summary report.

Ársæll Arnarsson og Sunna Gestsdóttir. (2021)

Andleg líðan unglinga í 10. bekk: Niðurstöður úr fyrirlögn Short Warwick-Edinburgh Mental Well-Being kvarðans.

Netla - Veftímarit um uppeldi og menntun: Sérrit 2021 - HBSC og ESPAD rannsóknirnar

Sótt af http://netla.hi.is/serrit/2021/HBSC_ESPAD_rannsoknir/02.pdf

DOI: https://doi.org/10.24270/serritnetla.2021.6 